\title{
Agriculture Accounting in India
}

\section{OPEN ACCESS}

Manuscript ID:

ECO-2020-08032431

Volume: 8

Issue: 3

Month: June

Year: 2020

P-ISSN: 2319-961X

E-ISSN: 2582-0192

Received: 29.03.2020

Accepted: 19.05.2020

Published: 01.06.2020

Citation:

Nandan, K. "Agriculture Accounting in India." Shanlax International Journal of Economics, vol. 8 , no. 3,2020 , pp. 110-113.

DOI:

https://doi.org/10.34293/ economics.v8i3.2431

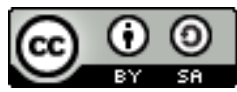

This work is licensed under a Creative Commons Attribution-ShareAlike 4.0 International License

\author{
K. Nandan \\ Department of Post Graduation and Research in Commerce \\ Kuvempu University, Shimoga, Karnataka, India \\ https://orcid.org/0000-0002-7341-2650
}

\begin{abstract}
India is an Agriculture based country where $50 \%$ of the population is based on agriculture. Agriculture is a main source of income to the Government. Agriculture accounting is very useful for agriculturist which helps them to know the income and expenses by agriculture activity. Therefore, a standard is introduced to provide a guidelines for agriculture Accounting called Ind AS41.Standaerd specifies the reorganization and measurement of Agriculture Assets, Gains and losses, Government subsides. It helps the agriculturist to avoid the unnecessary expenses and better utilization of available recourses.
\end{abstract}

Keywords: Gross Domestic Products (GDP), Indian Accounting Standard (Ind AS), Agriculture Accounting, Biological Assets, Agricultural Produce.

\section{Introduction}

Agriculture is a main backbone of our country. The agriculture is main Occupation of a people in our country. The Agriculture produce can be exported to other country. So, the agriculture creates $7.39 \%$ of the total GDP. The Agriculture Income is Exempt from income Tax. But the Income and expenses incurred from the agriculture practice must be accounted which helps the Agriculturist to know about the income and expenses. Where the expenses can be reduced by using some strategies. Though the agriculture accounting necessary to estimate the amount for expenses which may incur in future.

\section{Review of Literature}

1. Joanna, Michal (2016) made a study on "Agriculture Systems Supporting Farm Financial Management" in this study, they said that to know about the income and expenses. What are the expenses made for agriculture produce that to reduce those Expenses incurred for agriculture purposes? Any income gained for agriculture purpose they can be accounted for. This makes the agriculturist maintain a correct inflow and outflow of cash. (PAWŁOWSKA-TYSZKO, 2013)

2. Zeki Dogan (2013) made a study on "Historical Development of agricultural Accounting and Difficulties Encountered in the Implementation of Agricultural Accounting" in this study, they said that Agriculture Accounting makes the future estimation of costs. Income and expenses incurred can be easily known through Agriculture Accounting. The asset cost can be easily valued by the accounting method. Difficulties that are faced by the agriculturist can also be reduced through agriculture Accounting. (Doğan)

\section{Objectives of the Study}

- To know about agriculture accounting in India.

- To know the benefits to agriculturists from agriculture accounting.

- To know about the standard introduced for agriculture. 


\section{Agriculture}

Agriculture is an occupation where crops are grown and harvest, which is used for consumption by humans, industry, etc.

\section{Agriculture Accounting}

Agriculture Accounting is a method that income and expenses related to accounting are maintained in books of accounts.

\section{Benefits of Agriculture Accounting}

- It helps to know the income and expenses incurred.

- The strategies may imply to reduce the expenses.

- It helps to increase the efficiency of an agriculturist.

- It helps to know the actual profit from Agriculture.

- It helps in future estimation.

- It helps to know the cost of yield.

\section{Ind AS 41 Agriculture}

This standard is related to agriculture, where it provides guidelines for the treatment of agriculture accounting.

This Standard is applied to account for Biological Assets, Agricultural Produce, and Government Grants.

This standard is not applied for property, plant, and equipment, bearer plants, Intangible Assets related to agriculture activity.

Table: Example for Biological Assets and Agricultural Produce

\begin{tabular}{|c|l|l|}
\hline S. No & Biological Assets & Agriculture Produce \\
\hline 1 & Sheep & Wool \\
\hline 2 & Cotton plants & Harvested cotton \\
\hline 3 & Fruit trees & Fruits \\
\hline
\end{tabular}

\section{Recognition and Measurement of Agriculture} Activity

1. The entity controls the asset as a result of past events.

2. Future economic benefits associated with the asset will probably flow to the entity.

3. The fair value or cost of the asset can be measured reliably.
Biological Assets and Agriculture produce can be measured in the cost model and fair value less cost to sell method.

Fair value less cost to sell method: This method, the cost of expenses incurred to sell, is deducted by the fair value of biological assets and agriculture produce.

Cost model: Fair value is not available; the cost model is used to measure. In this method, depreciation should be deducted from the cost of Assets.

Anyone method is to fallow to measure the asset from starting to disposal of assets; there is no provision to change the measurement method.

\section{Gain and Losses}

Any gains and losses from the recognition of Biological Assets and agriculture Produce should be shown in the Profit and loss Account.

\section{Government Grants}

\section{Unconditional Grants}

Unconditional grants related to Biological Asset is received should be recognized in Profit and loss account.

\section{Conditional Grants}

Conditional Grants related to biological Assets are received should be recognized in profit and loss account when conditions are met.

\section{Methodology}

This study is based on both primary and secondary information/data. The study undertakes in the Chitradurga district. Primary data will be enumerated through direct interviews and questionnaires given to concerned respondents in the study area. To make the study, the Secondary data is gathered from different journals, newspapers, books, and relevant websites have been consulted. Farmers are selected randomly in the study area 50 respondents are selected. The present study is an attempt to know the information, features, and benefits of Agriculture Accounting.

Evaluation of Useful from the Introduction of Agriculture Accounting

\begin{tabular}{|c|c|}
\hline Responses & $\begin{array}{c}\text { Useful from Agriculture } \\
\text { Accounting (\%) }\end{array}$ \\
\hline Yes & 94.00 \\
\hline No & 6.00 \\
\hline
\end{tabular}


As per our survey, the total respondents are 50 in the total respondents, 47 respondents are answered that they are useful from agriculture Accounting, and the remaining 3 respondents answered as they are no useful from Agriculture accounting. This shows that Agriculture accounting is useful for agriculturists for agriculture activity.

Evaluation of an Increase in Income level of

\begin{tabular}{|c|c|}
\multicolumn{2}{c}{ Agriculturist } \\
\hline Response & $\begin{array}{c}\text { Increase in income level of } \\
\text { agriculturist (\%) }\end{array}$ \\
\hline Yes & 92.00 \\
\hline No & 8.00 \\
\hline
\end{tabular}

As per our survey, from 50 respondents, 46 respondents are answered that their income level is increased from Agriculture Accounting, and the remaining 4 Respondents answered that their income level is not changed, and there are no changes in income level of an agriculturist.

\section{Inference}

We can interpret from the above survey that Agriculture Accounting is useful to Agriculturist. Due to a lack of knowledge and information, in agriculturists, there is no proper use of Agriculture Accounting. So, with the proper information regarding this Accounting Standard can make them very easy in future estimation and proper utilization of resources.

\section{Findings}

- The introduction of agriculture accounting has become more useful to the agriculturist.

- It helps to find the income and expenses from activity.

- Expenses can be reduced through accounting.

\section{Suggestions}

- Agriculturists should get proper information related to the standard.

- Some training classes should be conducted to educate them.

- The government should take some measures to educate the Agriculturist.

\section{Conclusion}

Agriculture accounting plays a prominent role in India to know the agriculture income, which is also exempt from income tax. Accounts are to be prepared based on the standard. Where the expenses incurred from agriculture accounting can be known and also it may be reduced. It also helps in the correct utilization of funds. So, Agriculture standard shows to construct the accounts and to maintain it.

\section{References}

Argiles, J.M. et al. "A Comparative Study of Difficulties in Accounting Preparation and Judgment in Agriculture using Fair Value and Historical Coast For Biological Assets Valuation." Accounting Magazine, vol. 15, no. 1, 2012, pp. 109-142.

Argilés, J.M. and Eric John Slof. "New Opportunities for Farm Accounting." European Accounting Review, vol. 10, no. 2, 2001, pp. 361-383.

Arjun, K.M. "Indian Agriculture- Status, Importance and Role in Indian Economy." International Journal of Agriculture and Food Science Technology, vol. 4, no. 4, 2013, pp. 343-346.

Asumadu, Edward and Stephen Das. "Corporate Financial Reporting - A Study on the IFRS Regime in Ghana and Around the World." International Journal of Management Studies, vol. 5, no. 4(3), 2018, pp. 1-11.

Athanasios, Vazakidis, et al. "The Importance of Information through Accounting Practice in Agriculture Sector-European Data Network." Journal of Social Sciences, vol. 6, no. 2, 2010, pp. 221-228.

Breembroek, J.A. "Environmental Farm Accounting: The case of the Dutch Nutrients Accounting System." Agricultural Systems, vol. 51, no. 1, 1996, pp. 29-40.

Doğan, Zeki, et al. "Historical Development of Agricultural Accounting and Difficulties Encountered in the Implementation of Agricultural Accounting." International Journal of Food and Agriculture Economics, vol. 1, no. 2, pp. 105-114.

Herbohn, Kathleen and John Herbohn. "International Accounting Standard (IAS) 41: What are the Implications for Reporting Forest 
Assets?" Small-scale Forestry, vol. 5, 2006, pp. 175-189.

Karakaya, Meviut. "An Overview to Accounting Applications on Agricultural Activities in Turkey within Historical Progress." African Journal of Business Management, vol. 3, no. 7, 2009, pp. 294-304.

Pawłowska-Tyszko, Joanna, and Michał Soliwoda. "Agricultural Accounting Systems Supporting Farm Financial Management - The Case of Polish FADN." $3^{\text {rd }}$ Business and Management Conference, 2016, pp. 170-181.

Schnitkey, G.D. and Steven T. Sonka. "Systems Design Procedures for Farm Accounting." Southern Journal of Agricultural Economics, vol. 18, no. 2, 1986, pp. 207- 214.

Schnitkey, G.D. "Farm Accounting Systems and Information Usage." Review of Agricultural Economics, vol. 13, no. 1, 1991, pp. 109-117.

Sedláček, J. "The Methods of Valuation in Agricultural Accounting." Agricultural Economics (Czech Republic), vol. 56, no. 2, 2010, pp. 59-66. 2010

Sharafat, A.A. "The Impact of the Use of Agricultural Accounting on the Financial Performance of
Broiler Industry: A Comparative Evaluation Approach on Broiler Industry in Jordan." Journal of Agricultural Science, vol. 8, no. 12, 2016, pp. 164-171.

Sharma, R.S. "Accounting for Agriculture." International Journal of Recent Research and Review, vol. 2, 2012, pp. 62-66.

Wheeling, Barbara. Introduction to Agriculture Accounting. Thomson Publication, 2007.

Williamson, Paul. "Farm Accounting, Donald R. Mitchell, New York, McGraw-Hill Book Company, 1941. Pp. 227, \$2.50.” American Journal of Agricultural Economics, vol. 23, no. 4, 1941, pp. 921-922.

https://mca.gov.in/Ministry/pdf/INDAS41.pdf

https://www.iasplus.com/en/standards/ias/ias41

https://www.slideshare.net/DilipPunjabi1/ agriculture-accounting

https://www.slideshare.net/ronelcana/farm-recordsand-accounting

https://caknowledge.com/ind-as-41

https://indasprep.com/category/ind-as/ind-as-41agriculture

https://www.coursehero.com/file/51346964/Ind-AS$41 \mathrm{pdf}$

\section{Author Details}

K. Nandan, Department of Post Graduation and Research in Commerce, Kuvempu University, Shimoga, Karnataka, India, Email ID: nandank.cta@gmail.com. 